\title{
DIMENSI POLITIK EKOLOGI DALAM KERJASAMA VOLUNTARY PARTNERSHIP AGREEMENT (VPA) INDONESIA-UNI EROPA
}

\author{
Bahjatul Murtasidin \\ IImu Politik Universitas Bangka Belitung \\ bmurtasidin@gmail.com \\ Bob Morison Sigalingging \\ Sastra Inggris Universitas Bangka Belitung
}

\begin{abstract}
Abstrak
Penelitian ini bertujuan untuk menjelaskan dimensi ekologi politik dalam kerjasama yang di lakukan Indonesia-Uni Eropa melalui Voluntary Partnership Agreement (VPA). Metode yang dilakukan dalam penelitian ini adalah kualitatif dengan pendekatan analisis deskriptif. Hasil penelitian ini menunjukkan bahwa kerangka kerjasama Voluntary Partnership Agreement (VPA) Indonesia-Uni Eropa yang terbangun sangat kental dengan dimensi ekologi politiknya. Bagaimana tidak, dalam kesepakatan ini kedua pihak berkomitmen untuk hanya memperdagangkan kayu yang legal dan proses dari hulu sampai hilir harus berprinsip pada perbaikan tata kelola hutan yang lebih baik. Selain itu, nuansa ekonomi politik yang menjadi tonggak penting dalam pengembangan awal ekologi politik juga sangat terlihat dalam kerjasama ini. Indonesia tetap bisa melakukan ekspor kayu sebagai salah satu komoditas unggulannya ke UE dengan catatan memiliki aspek lagalitas kayu yang jelas. Begitu juga sebaliknya, UE hanya mengizinkan ekspor kayu Indonesia untuk masuk kawasan UE jika tersertifikasi. Ini merupakan sebuah sintesa (solusi) antara kebutuhan dengan usaha mempertahankan lingkungan yang ada dari kerusakan akibat eksploitasi.
\end{abstract}

Kata Kunci:

Ekologi Politik, Kayu Legal, Voluntary Partnership Agreement

\begin{abstract}
This paper has the objective of describing the dimension of ecological politics in cooperation between Indonesia and the European Union through the Voluntary Partnership Agreement (VPA). In an attempt to make the composition, a qualitative method with a descriptive analysis approach was applied. The striking result to emerge from the data is that the existed framework of VPA between Indonesia and the EU is highly powerful with the dimension of ecological politics. It is obvious that in this agreement both parties commit to only trade legal timber and the process from the upstream to downstream must be based on the principles of improving good forest governance. Moreover, the nuance of the political economy that becomes an essential milestone in the early development of ecological politics is also vividly seen in this cooperation. Indonesia can still export the wood as one of its leading commodities to the EU with a record of holding clear aspects of timber legality. Unfortunately, the EU only permits Indonesian timber export to enter the EU if certified. This is a synthesis (solution) between needs and efforts to maintain the existing environment from damage due to exploitation.
\end{abstract}

Keywords:

ecological politics, legal timber, Voluntary Partnership Agreement 


\section{PENDAHULUAN}

Penelitian ini mencoba menguraikan dimensi politik ekologi dalam kerangka kerjasama Voluntary Partnership Agreement (VPA) Indonesia-Uni Eropa. Peneliti memilih tema ini sebagai objek penelitian disebabkan oleh beberapa alasan. Pertama, Indonesia pernah memperoleh prediket sebagai negara penghasil kayu ilegal (illegal logging) akibat dari sejarah tata kelola, tata kuasa, dan tata produksi hutan yang buruk. Sedangkan Uni Eropa juga pernah mendapatkan prediket sebagai negara "penikmat" kayu ilegal dari Indonesia. Kedua, Indonesia merupakan negara Asia pertama yang menandatangani kerja sama ini pada 30 September 2013 di Brussel, Belgia (Savirra 2014), dan baru diratifikasi pada tanggal 27 Februari 2014 di Strasbourg, Prancis (Kunkunrat \& dan Hariyadi 2017). Ketiga, kerjasama ini merupakan hasil dari proses panjang negosiasi antara Indonesia dan Uni Eropa sejak 2007 dalam merespon isu legalitas kayu di pasar internasional dengan segala macam bentuk perdebatan politik berdimensi ekologi yang pada akhirnya sepakat untuk hanya melakukan ekspor dan impor produk kayu yang terverifikasi legal.

Banyak negara mulai melakukan proses sertifikasi dan regulasi terhadap produk hasil hutan dari kejahatan yang mengakibatkan pada kerusakan di kawasan hutan pasca Deklarasi Bali tentang Forest Law Enforcement Governance pada tahun 2001 (Kunkunrat \& dan Hariyadi 2017). Kemudian, selama antara tahun 2002-2010, menjadi rentang waktu yang digunakan oleh banyak pihak untuk membicarakan isu illegal logging. Banyak sekali ragam kegiatan yang kemudian dilakukan terkait dengan isu ini, apalagi pihak Uni Eropa (UE) sebagai salah satu konsumen terbesar produk kayu yang mengembangkan aturan untuk meningkatkan kualitas lingkungan hidup melalui penerapan Forest Law Enforcemet Governance (FLEGT) (Hawin, Nurhayati, dan Antoni 2010).

Tujuan utama dari FLEGT ini sepaling tidak mencakup tiga hal. Pertama, sebagai sarana untuk membantu negara-negara produsen kayu meningkatkan tata kelola (governance) dan "capacity building" dalam memberantas penebangan secara liar yang sering terjadi. Kedua, sebagai upaya untuk mencegah atau mengurangi penggunaan kayu ilegal dan investasi UE yang disalahgunakan dan mengakibatkan terjadinya illegal logging. Ketiga, untuk mencegah penggunaan kayu illegal dan investasi UE pada kegiatan yang menimbulkan kegiatan pencurian kayu (over cutting) (Komisi Eropa 2007). Untuk melaksanakan tujuan FLEGT tersebut, terutama pada tujuan terakhir, maka UE menerapkan kerangka kerjasama Voluntary Partnership Agreement (VPA) kepada negara-negara pengekspor kayu, tidak terkecuali Indonesia.

\section{STUDI LITERATUR}

Menurut Cornelis Lay, hampir setiap bangsa di dunia ini telah menempatkan lingkungan sebagai bahasa bersama dalam matarantai politik yang menghubungkan sebuah bangsa dengan komunitas global. Lingkungan telah menjadi ideologi humanisme di antara bangsa komunitas dan individu dari banyak ras, ideologi, kebudayaan dan tingkatan ekonomi. Lingkungan juga menjadi titik episentrum paling netral dan kuat, tetapi sekaligus paling subjektif dari masyarakat manusia. Di dalam isu lingkungan melekat kepentingan subjektif manusia, masa depan bersama dari bukan saja sebuah bangsa tetapi setiap komunitas dan individu pembentuk bangsa. Dengan posisi seperti di atas tidak mengherankan jika isu lingkungan telah menjadi salah satu dari sedikit isu bersama masyarakat global yang melahirkan jaringan 
interaksi politik yang paling kompleks. Lingkungan melahirkan pola-pola interaksi dengan variasi yang paling rumit dan sekaligus dengan pelibatan aktor yang paling majemuk. Konflik dan kerjasama antar negara, antar daerah atau antar pemerintahan, antara pemerintah dan masyarakat, antara masyarakat dan dunia usaha, dan masih banyak lagi sudah menjadi tema penting yang menghubungkan aktor-aktor yang bervariasi dan sekaligus telah menjadi objek penting dalam berbagai kajian ilmu politik (Lay 2007).

Karakteristik khas yang melekat pada lingkungan dapat dijadikan titik rujuk bagi politik sebagai instrumen pengaturan kepentingan bersama. Setidaknya, ada tiga karakteristik dasar lingkungan yang bisa diidentifikasi (Lay 2007). Pertama, watak lingkungan sebagai sebuah kesatuan sistem melintasi sekat-sekat administrasi pemerintahan dan politik. Lingkungan tidak pernah setia pada dan tidak pernah bisa dipagari oleh ruang yang diciptakan melalui politik. la melintasi batasbatas negara, mengabaikan konseptualisasi tentang "kedaulatan" sebagai titik pijak dalam pemaknaan atas negara modern. Sifat lingkungan juga tidak pernah setia pada dan tidak dapat dipagari oleh batas-batas administrasi pemerintahan apapun pola pengaturannya.

Kedua, lingkungan melekat di dalamnya kepentingan paling subjektif dari manusia sebagai makhluk, terlepas dari ruang politik dan terbebas dari penjara waktu. Setiap individu, membutuhkan lingkungan sebagai ruang kebutuhan hari ini yang tak bisa ditunda pemenuhannya dan sekaligus ruang kebutuhan masa depan yang tak dapat dipercepat. Lingkungan adalah ruang kita sebagai makluk manusia bukan saja sebagai ruang hari ini, tapi sekaligus sebagai ruang masa depan diri dan anak keturunan kita. Dalam konteks ini, lingkungan memiliki variasi makna, mulai dari posisinya sebagai ruang ekonomi, ruang kultural, bahkan hingga pada ruang dalam makna fisikalnya. Karena alasan di atas, lingkungan dapat berfungsi sebagai basis pertama dan terutama dalam pengaturan politik masa kini dan masa depan. Hal ini memungkinkan lingkungan menyediakan insentif bagi politik untuk berfungsi sebagai instrumen untuk mencapai collectiae gain.

Ketiga, daya menghukum lingkungan yang timbul sebagai akibat dari pengabaian manusia atas lingkungan punya sifat yang sangat khas, yakni indiskriminatif. Berbagai bencana dan kenaasan yang timbul silih berganti sebagai akibat logis dari kealpaan kita memperlakukan lingkungan secara wajar akan melanda siapa saja tanpa memperdulikan kelas sosial, kekayaan, asal-usul, suku, agama dan berbagai kategori pembeda manusia lainnya.

Karena alasan-alasan di atas, sangat masuk akal jika lingkungan bisa menjadi energi bersama untuk menghidupi politik sebagai seni untuk mengatur kepentingan bersama. Teori politik ekologi berkembang pesat seiring dengan kajian lingkungan yang mulai menggabungkan dinamika lingkungan lokal ataupun global dengan pendekatan ekonomi dan politik. Menurut Paterson bahwa politik lingkungan adalah suatu pendekatan yang menggabungkan masalah lingkungan dengan politik ekonomi untuk mewakili suatu pergantian tensi yang dinamik antara lingkungan dan manusia, dan antara kelompok yang bermacam-macam di dalam masyarakat skala dari individu lokal kepada transnasional secara keseluruhan (Hidayat 2008)

Teori politik ekologi menurut Bryant dan Bailey terbagi pada dua periode. Periode pertama, tahun 1970an hingga 1980an. Periode ini kajian tentang ekologi politik mengacu pada teori Neo Marxian yang menjelaskan hubungan masyarakat lokal dan kerusakan lingkungan dengan kekuatan ekonomi dan politik supra desa 
dan merupakan kritik terhadap Neo-Malthusian dan ekologi budaya. Kajian ekologi politik pada periode ini menggunakan analisis struktural yang melihat konflik akibat dari proses produksi global. Periode kedua, tahun 1980an hingga 1990an. Kajian ekologi politik pada periode ini mengacu pada teori Neo Weberianisme, teori gerakan sosial dan teori feminisme, dan serta merupakan kritik terhadap NeoMarxism. Fokus kajian pada perubahan pada berbagai tingkatan sebagai hasil interaksi seluruh aktor yang memiliki kekuasaan dengan tekanan analisis pada ketidakseimbangan kekuasaan berbagai aktor, dan motif serta kepentingan dari aktor tersebut (Bryant LR dan Bailey 2000).

Perkembangan politik lingkungan biasanya berkaitan dengan politik penguasaan dan pemilikan sumber daya alam dan perdagangan produknya. Dalam hal ini politik berkaitan dengan kekuatan dan kekuasaan pasar. Selain itu, politik lingkungan juga menganalisis peran institusi atau pihak-pihak yang berkepentingan dengan sumber daya alam dan lingkungan. Di sini, peran masyarakat, pemerintah, swasta, organisasi non pemerintah, lembaga pembangunan, pendidikan dan penelitian juga dianalisis (Dauvergne, 2005). Sebagaimana yang dikutip dari Tony Djoga dalam tulisannya Politik Lingkungan menyatakan bahwa "Politik lingkungan menganalisis persoalan kerusakan lingkungan yang disebabkan oleh pasar namun tidak dapat dikontrol oleh pasar. Pasar dan swasta memiliki kekuasaan dan kontrol walaupun tidak memiliki kewenangan atas sumber daya alam. Akibat dari perilaku dan tindakan pasar terjadi eksternalitas yang kemudian membutuhkan intervensi pemerintah atatu tata kelola (Governance) lain untuk menanganinya. Pemerintah dapat menindak sebagai salah satu bentuk tindakan hukum namun juga dapat memberikan intensif untuk mendorong masyarakat atau swasta untuk lebih bertanggung jawab terhadap lingkungan"

Kajian politik ekologi semakin dikuatkan dengan pandangan modernisme (Beck U 1992). Pemikiran modernisme berawal dari kesadaran masyarakat terhadap resiko. Pendekatan modernisme berpendapat bahwa bencana di masa depan harus diminimalisir dengan mereduksi resiko yang dapat merusak kehidupannya seperti bencana alam. Keberadaan bencana akan merusak capaian pembangunan yang telah terealisasi. Filosofi pendekatan ini mengacu pada manusia harus bersahabat dengan lingkungan agar dapat mengelola dampak/resiko dari kerusakan lingkungan sehingga harus mengontrol perilaku dirinya dalam menggunakan sumberdaya dan mencari alternatif penggunaan sumberdaya yang memiliki resiko kecil bagi kehidupan manusia. Forsth juga menjelaskan kajian politik ekologi tidak terlepas dari pengaruh kapitalisme terhadap lingkungannya. Beberapa isu dominan dalam kajian ekologi politik, seperti degradasi dan marginalisasi, konflik lingkungan, konservasi dan pengendalian, identitas lingkungan dan gerakan sosial serta objek politik dan aktor (Robbins 2012).

\section{METODE PENELITIAN}

Penelitian ini merupakan penelitian yang dilakukan dengan menggunakan pendekatan kualitatif (qualitative research) dan metode pengumpulan datanya adalah studi pustaka (library research). Untuk menjelaskan dimensi ekolologi dalam kerjasama Valuntary Partnership Agreement (VPA), penulis menggunakan model analisis interaktif yang dikemukakan oleh Miles dan Huberman. 
Gambaran analisis interaktif Miles dan Huberman dapat dilihat seperti diagram berikut :

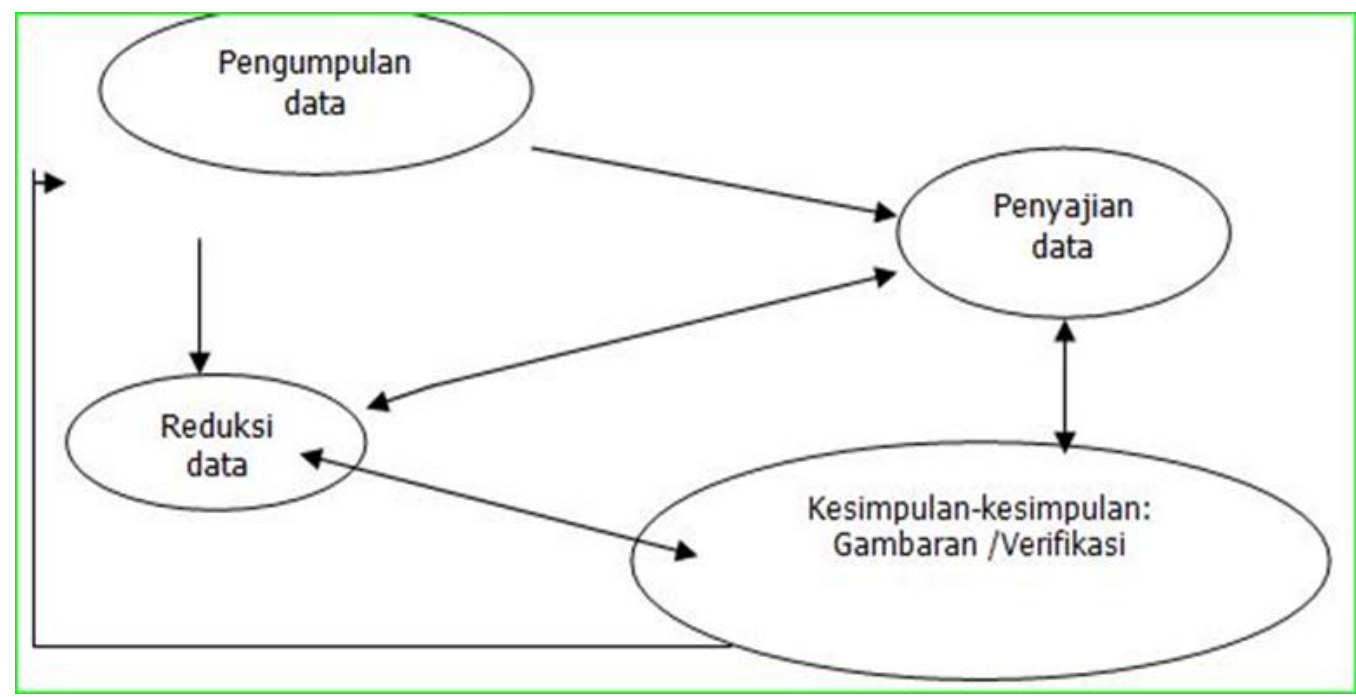

Sumber: Muhammad ldrus., 2009

Model analisis ini terdiri dari beberapa kegiatan: (1) pengumpulan data, (2) reduksi data, (3) penyajian (display) data, dan (4) verifikasi atau penarikan kesimpulan. Model analisis ini dikatakan sebagai model interaktif karena rangkaian kegiatan tersebut jalin-menjalin pada saat sebelum, selama, dan sesudah pengumpulan data dalam bentuk yang sejajar untuk membangun wawasan umum yang disebut analisis, dengan kata lain kegiatan pengumpulan data dan tiga kegiatan lainnya merupakan proses siklus dan interaktif.

\section{PEMBAHASAN}

Pembalakan liar (illegal logging) adalah penebangan kayu yang bertentangan dengan hukum dan peraturan negara tempat penebangan dilakukan. Illegal Logging merupakan masalah global dengan dampak negatif yang signifikan secara ekonomi, lingkungan dan sosial. Hal ini dapat dilihat dalam bidang ekonomi hasil illegal logging menghasilkan kerugian dan kehilangan manfaat-manfaat yang bisa diperoleh sebelumnnya. Dalam bidang lingkungan, illegal logging dikaitkan dengan deforestasi, perubahan iklim, dan hilangnya keanekaragaman hayati. Sedangkan dalam bidang sosial, illegal logging dapat dihubungkan dengan konflik atas tanah dan sumber daya, ketidakberdayaan masyarakat lokal dan masyarakat adat, korupsi dan konflik bersenjata. Kegiatan ilegal juga merusak upaya operator yang bertanggungjawab dengan tersedianya produk kayu yang harganya lebih murah tapi ilegal yang dimana menurut Bank Dunia memperkirakan bahwa pihak pemerintah di beberapa negara termiskin di dunia mengalami kerugian lebih dari 15 milyar US dollar per tahun sebagai dampak dari illegal logging.

Praktik illegal logging di Indonesia pasca tahun 1960an mulai luas dan berskala besar dengan aktor yang terlibat melakukan illegal logging adalah para pemegang Hak Pengusahaan Hutan $(\mathrm{HPH})$, sekarang dikenal dengan Izin Usaha Pemanfaatan Hasil Hutan Kayu (IUPHHK). Pembuatan sistem HPH awalnya 
diperuntukkan bagi pemanfaatan produksi hasil hutan yang terkontrol dan ada upaya regenerasi hutan oleh para pemegang $\mathrm{HPH}$. Namun dalam implementasinya proses pemberian HPH tanpa transparansi dan beberapa kewajiban untuk meregenerasi hutan tidak dilakukan oleh pemegang $\mathrm{HPH}$. Kurangnya fungsi pengawasan dan kontrol oleh pemerintah serta adanya kerja sama antara aktor yang melakukan illegal logging dengan jajaran birokrat kehutanan mengakibatkan terjadinya eksploitasi berlebihan dalam pemanfaatan hutan.

Dengan mempertimbangkan hal tersebut, maka Voluntary Partnership Agreement atau yang selanjutnya disebut VPA hadir sebagai mekanisme yang dibuat UE dalam merespon illegal logging. Sebagai negara konsumen kayu, UE telah mengalami dampak langsung illegal logging, di mana hampir sebagian besar kayu atau produk kayu yang masuk di UE diperkirakan ilegal. Sedangkan hal ini bertentangan dengan komitmen UE untuk melaksanakan program yang peduli lingkungan. Sadar bahwa illegal logging terus berlangsung karena adanya pasar, selaku negara konsumen UE kemudian menjalin kerja sama bilateral dengan negara-negara produsen kayu melalui VPA. berikut:

Tahapan pelaksanaan VPA secara lengkap terdiri dari empat tahap, sebagai

1. Tahap persiapan atau pra-perundingan. Pada tahap ini, Indonesia sebagai negara produsen kayu mempelajari lingkup model VPA dan memperkirakan apakah kebutuhan sektor kehutanan akan terpenuhi jika menjalin kerjasama. Dengan kata lain, dalam fase ini merupakan awal negosiasi di internal Indonesia untuk melakukan berbagai pertimbangan dan masukan apakah akan melanjutkan pada tahapan berikutnya.

2. Tahap perundingan. Pada tahap ini mitra menyepakati standar dan sistem jaminan, dan di atasnya mereka akan mendasarkan kesepakatan perdagangan kayu mereka.

3. Tahap pengembangan, di mana para pihak mengembangkan sistem seperti yang telah disepakati serta mengevaluasi kredibilitasnya; dan

4. Tahap pelaksanaan penuh, di mana sistem ini sudah mulai berjalan dan hanya kayu legal berijin yang dapat diekspor dari negara mitra ke pasar UE. Apabila suatu negara mitra dagang sudah menandatangani VPA dan VPA sudah diimplementasikan secara penuh, maka sebagai konsekuensinya bila negara mitra tersebut akan mengekspor kayu dan produk kayu ke UE harus memperoleh izin melalui skema lisensi.

Berdasarkan tahapan proses VPA di atas, dapat diketahui bahwa fokus dari perjanjian kerja sama VPA ini bertitik pada permasalahan-permasalahan yang tingkat urgensinya tinggi seperti pengelolaan hutan namun tidak melewatkan kelestarian hutan itu sendiri. Fokus dari VPA adalah untuk memastikan 3 pilar pengelolaan hutan lestari (sustainable forest management) yang diantaranya adalah lingkungan, ekonomi, dan sosial-budaya. Dan pada intinya, perjanjian yang terjalin ini akan memberi penejelasan akan konsep legalitas kayu berdasarkan hukum kehutanan di Indonesia yang mana telah disesuaikan dengan peraturan negara mitra yaitu UE.

VPA menawarkan pendekatan sebagai upaya dalam merumuskan dan menegosiasikan mekanisme verifikasi legalitas kayu (SVLK) agar kayu yang diproduksi dan diekspor ke UE dapat dikenali dengan menggunakan identitas atau 
lisensi yang dikeluarkan oleh lembaga yang ditunjuk. Adapun skema lisensinya meliputi tiga aspek berikut: Pertama, verifikasi untuk membuktikan bahwa pemanenan kayu, transportasi, dan perdagangannya telah memenuhi peraturan perundangundangan yang ditentukan. Kedua, pelacakan (chain of custody) untuk memastikan bahwa kayu dari hutan sampai ke UE tanpa tercampur dengan kayu yang tidak jelas asal usulnya. Ketiga, penerbitan lisensi yang menunjukkan bahwa legalitas kayu telah diverifikasi.

VPA melengkapi upaya Rencana Aksi FLEGT lainnya, yakni Peraturan Kayu Uni Eropa (European Union Timber Regulation) tahun 2013. Peraturan tersebut melarang memasukkan kayu ilegal ke pasar UE. Hal ini berlaku untuk kayu domestik dan impor. Ini merupakan bagian dari upaya mengatasi pembalakan liar yang terjadi sekaligus menghilangkan prediket sebagai negara penikmat kayu ilegal. Oleh karena itu, VPA merupakan kesepakatan kemitraan sukarela perdagangan bilateral yang bertujuan untuk menjamin hanya produk kayu terverifikasi legal dari negara mitra yang dapat memasuki pasar UE. Selain untuk mempromosikan perdagangan kayu legal, VPA juga menyasar penyebab tidak legalnya suatu produk melalui perbaikan tata kelola hutan dan penegakan hukum.

Tujuan utama dari VPA Indonesia-UE adalah untuk menyediakan suatu kerangka legal guna menjamin seluruh produk kayu yang diimpor oleh EU dari Indonesia telah diproduksi secara legal, sebagaimana dibahas dalam kesepakatan. Lampiran VPA menjelaskan perangkat hukum dan peraturan di Indonesia yang diterapkan di sektor kehutanan Indonesia dan sistem kontrol serta prosedur verifikasi yang menjamin semua kayu dan produk kayu yang diekspor dari Indonesia ke UE telah menaati peraturan perudang undangan tersebut. Hal ini karena kedua pihak berkomitmen untuk hanya memperdagangkan produk-produk kayu yang legal.

VPA menjabarkan suatu sistem yang memverifikasi legalitas produk-produk kayu yang legal. Sistem verifikasi legalitas kayu tersebut akan menerbitkan FLEGT License untuk menyertai ekspor produk-produk perkayuan Indonesia yang sudah diverifikasi legalitasnya ke negara-negara UE. Ekspor ke pasar-pasar lain dilampiri Dokumen V-Legal. Dengan demikian, Indonesia kemudian hanya akan mengekspor produk-produk perkayuan ber-FLEGT Licence ke UE dan UE hanya mengizinkan ekspor kayu Indonesia untuk masuk kawasan UE jika disertai FLEGT License yang sah.

VPA diperkenalkan oleh UE melalui peraturan (EC) No. 2173/2005 yang merupakan mekanisme untuk mengidentifikasi dan mengeluarkan kayu ilegal dari pasar UE (Hawin, Nurhayati, dan Antoni 2010). Elemen kunci dalam VPA adalah untuk mendorong negara mitra mengembangkan sistem administrasi dan teknis legalitas yang kredibel untuk memverifikasi kayu berdasarkan hukum (Heeswijk, I. v., \& Turnhout 2013). Sistem Administrasi tersebut dinamakan TLAS atau Timber Legallity Anssurance System yang dapat menunjukkan identitas asal kayu yang diproduksi dan diekspor ke UE.

Ketentuan skema lisensi di atas mengisyaratkan bahwa semua kayu yang hendak diperdagangkan ke pasar UE harus memenuhi proses sistem verifikasi legalitas kayu. Di Indonesia, sistem verifikasi legalitas kayu yang digunakan adalah Sistem Verifikasi Legalitas Kayu (SVLK). Indonesia mengembangkan SVLK ini untuk memastikan bahwa semua produk kayu yang dipanen, diimpor, diangkut, diperdagangkan diproses dan diekspor patuh pada hukum yang berlaku terkait dengan aspek lingkungan, sosial, dan ekonomi sebagaimana yang telah 
diidentifikasikan para pihak dari pemerintah, sektor swasta, dan masyarakat sipil. SVLK ini terbuka bagi pemantauan independen oleh masyarakat sipil dan evaluasi berkala oleh auditor. Perkembangan SVLK yang dilakukan oleh Indonesia sejalan dengan VPA UE, karena substansi dari VPA itu sendiri yaitu adanya suatu sistem yang menjamin legalitas kayu yang diproduksi oleh negara mitra.

SVLK adalah forest certification dan sistem penjaminan legalitas kayu Indonesia yang dibangun dan dikembangkan oleh multistakeholder sejak tahun 2003. SVLK ditetapkan sebagai sebuah kebijakan sejak tahun 2009 melalui Peraturan Menteri Kehutanan (Permenhut) Nomor P.38/Menhut-II/2009 jo Peraturan Menteri Lingkungan Hidup dan Kehutanan (PermenLHK) Nomor P.95/MenhutII/2014 tentang Standar dan Pedoman Penilaian Kinerja Pengelolaan Hutan Produksi Lestari dan Verifikasi Legalitas Kayu pada Pemegang Izin atau pada Hutan Hak.

SVLK merupakan upaya soft approach yang dilakukan pemerintah Indonesia untuk perbaikan tata kelola pemerintahan atas maraknya illegal logging dan sekaligus sebagai upaya penindakan hukum (hard approach) yang selama ini telah digunakan pemerintah. Soft approach dari skema SVLK memberi perbaikan terhadap tata usaha dan administrasi perkayuan dengan mekanisme yang dapat dipantau semua pihak dan memiliki kredibilitas dalam implementasinya.

Gambar 1.2. Skema SVLK

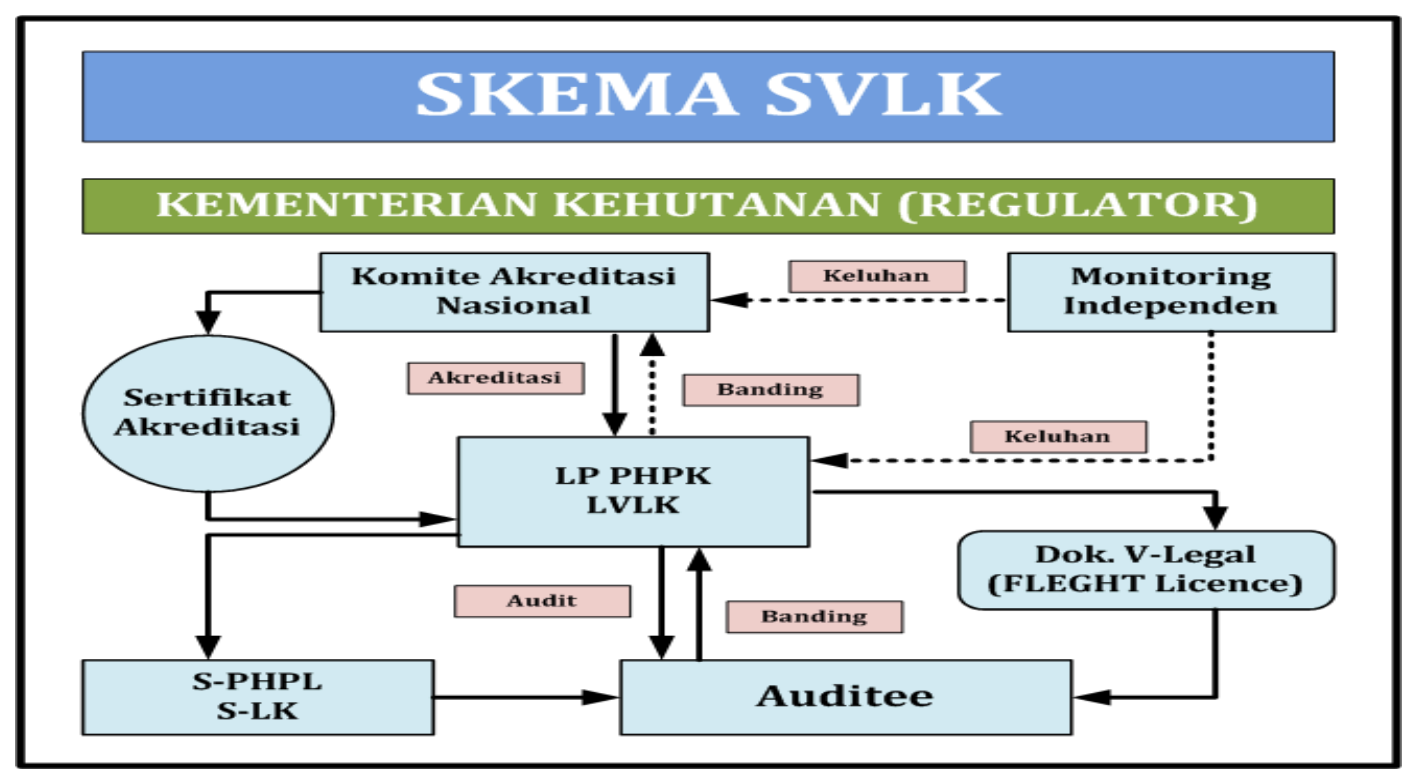

Sumber : FWI, 2012

Lebih lanjut, SVLK merupakan sistem yang mencakup hulu (negara produsen kayu) dan hilir (negara konsumen kayu) dengan prinsip perbaikan tata kelola lebih baik (governance), keterwakilan para pihak dalam pengembangan dan pemantauannya (representatives) serta transparansi (transparent) yang dapat diawasi semua pihak. Di hulu Suistainable Forest Management adalah hal yang harus dipenuhi produsen kayu agar di hilir legalitas kayu telah terjamin.

Wilayah Indonesia yang luas membuat penanganan pembalakan liar harus melibatkan berbagai pihak dengan kerjasama dan koordinasi secara bilateral maupun multilateral, baik dengan negara, organisasi-organisasi pemerintah dan organisasi-organisasi non pemerintah. Memerangi llegal Logging memerlukan 
komitmen dan keterlibatan aktif oleh negara untuk merumuskan suatu regulasi atau kebijakan dalam menangani permasalahan tersebut. Ketika regulasi tersebut diratifikasi apakah mampu mencegah dan menangani perdagangan ilegal khususnya di Indonesia.

Sebelumnya, tidak ada mekanisme yang dapat membantu bea cukai untuk mengenali kayu ilegal dan mencegahnya untuk tidak memasuki pasar UE. UE kemudian mengadopsi Regulasi No. 2173/2005, tanggal 20 Desember 2005 yang pada intinya adalah penetapan suatu "Licesing Scheme" untuk produk kayu ke UE melalui kemitraan dengan negara produsen kayu (Savirra 2014). Berdasarkan hal tersebut, dalam VPA ini mengeluarkan suatu lisensi yang dapat memastikan bahwa produk kayu yang telah mendapatkan lisensi tersebut merupakan kayu legal, yaitu lisensi FLEGT. Lisensi FLEGT ini merupakan output dari VPA. Dengan mendapatkan lisensi FLEGT ini, menandakan bahwa produk kayu tersebut telah melewati proses legal sebagaimana dalam aturan yang menetapkan legalitas kayu dalam negara mitra tersebut. Indonesia merupakan negara pertama di dunia yang berhasil meraih lisensi FLEGT dari UE.

Produsen kayu yang sesuai dengan sistem jaminan legalitas kayu (SVLK) harus melampirkan Dokumen V-Legal untuk produk mereka yang akan di ekspor ke setiap pasar internasional. Dimulai dengan pemberlakuan Peraturan Menteri Lingkungan Hidup dan Kehutanan No. 30/2016 dan Peraturan Menteri Perdagangan No. 30/2016, yang mewajibkan untuk menggunakan dokumen V-Legal untuk ekspor kayu yang tercakup dalam VPA, merupakan wujud kesiapan Indonesia untuk memulai penerbitan lisensi FLEGT. Dokumen V-Legal menetapkan bahwa produk kayu yang diangkut sesuai dengan legalitas atau standar keberlanjutan dan persyaratan kontrol rantai pasokan sebagaimana diatur dalam peraturan Indonesia dan VPA. Jadi Dokumen V-Legal memberikan jaminan bahwa kayu atau produk kayu yang legal. Sehingga, V-legal merupakan instrumen penting dalam aktivitas ekspor Indonesia, khususnya ke UE. Adapun proses untuk mendapatkan dokumen V-legal sebagai berikut :

\section{Gambar 1.4. Alur Proses Penerbitan Dokumen V-Legal}

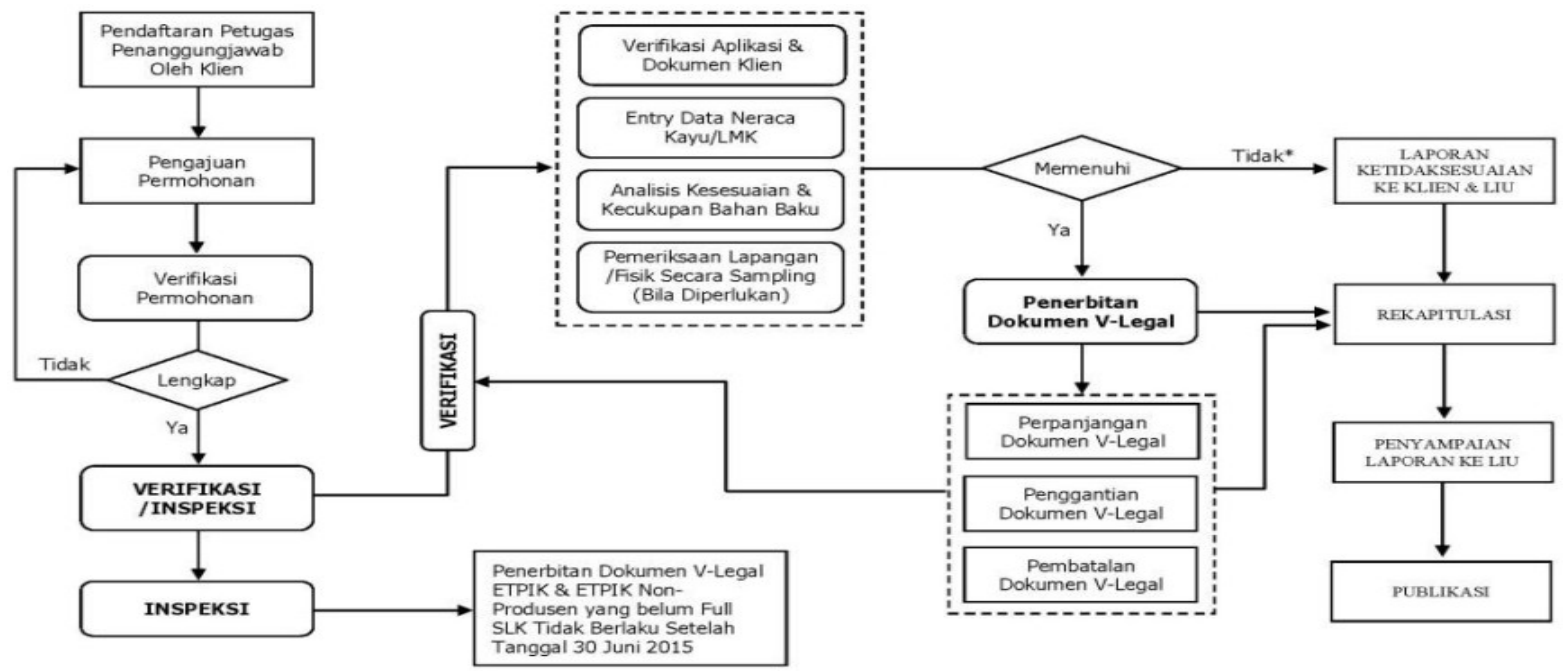

Sumber : www.lambodjasertifikasi.com 
Sampai pada tahap penerbitan V-legal ini terlihat jelas bagaimana sebenarnya sasaran atau target dari perjanjian ini pada dasarnya juga untuk mempromosikan peran hutan di Indonesia yang adil dan berkelanjutan. Dalam pencapaian tujuan tersebut akan mendukung dan mendorong pemerintah Indonesia, sektor swasta (industri) dan masyarakat sipil untuk menciptakan kondisi yang kondusif dalam mengurangi penebangan ilegal dan perdagangan kayu ilegal serta praktek perusakan hutan. Hasil utama diturunkan menjadi kegiatan dari proyek ini, antara lain:

1. Meningkatnya tata kelola pemerintahan dalam bidang kehutanan melalui akuntabilitas dan transparansi;

2. Berkurangnya perdagangan produk kayu yang ilegal dan promosi terhadap perdagangan produk kayu yang legal;

3. Adanya kajian atas sistem silvikultur dan pengapdopsian sistem yang sesuai dengan badan verifikasi pihak ketiga; dan

4. Meningkatnya koordinasi aktivitas di bawah bendera FLEGT dan terjalin hubungan antara para donor, organisasi internasional lainnya dan pemerintah Indonesia.

Perjanjian kerjasama FLEGT-VPA dinilai menjadi jalan tengah bagi kedua negara yang saling bermitra untuk mencapai kepentingan nasionalnya masingmasing dalam permasalahan kehutanan. Dengan adanya kerjasama VPA membuat kedua pihak terikat dan harus menjalankan prosedur-prosedur yang tertuang dalam isi perjanjian yang telah disetujui oleh kedua belah pihak.

Dari sudut pandang politik ekologi, perubahan lingkungan (baik kerusakan maupun upaya perbaikannya) adalah merupakan hasil dari kebijakan ekonomi dan politik yang muncul dari hasil pergumulan berbagai aktor di dalam konteks suatu negara, interaksinya diantara negara, dan dalam konteks perkembangan kapitalisme global. Disinilah kira-kira muatan ekologi politik dalam kerangka kerjasama Voluntary Partnership Agrement (VPA) yang di bangun oleh Indonesia dan UE. Proses dari hulu sampai hilir tetap berprinsip pada perbaikan tata kelola hutan yang lebih baik. Selain itu, nuansa ekonomi politik yang menjadi tonggak penting dalam pengembangan awal ekologi politik juga sangat terlihat dalam kerangka kerjasama ini. Indonesia tetap bisa melakukan ekspor kayu sebagai salah satu komoditas unggulannya ke UE dengan catatan memiliki aspek lagalitas kayu yang jelas, dibuktikan dengan proses SVLK dan dokumen V-legal. Begitu juga sebaliknya, UE hanya mengizinkan ekspor kayu Indonesia untuk masuk kawasan UE jika tersertifikasi. Ini merupakan sebuah sintesa (solusi) antara kebutuhan dengan usaha mempertahankan lingkungan yang ada dari kerusakan akibat eksploitasi hutan.

\section{KESIMPULAN}

Voluntary Partnership Agreement (VPA) Indonesia - UE merupakan kerjasama yang sangat identik dengan dimensi ekologi politik. VPA mengisyaratkan aspek legalitas kayu dan Indonesia menggunakan Sistem Verifikasi Legalitas Kayu (SVLK) sebagai sistem verifikasi legalitas kayunya. SVLK adalah sebuah upaya yang diberlakukan pemerintah untuk memperbaiki tata kelola sektor kehutanan atas maraknya tindakan pembalakan liar disamping upaya penindakan secara hukum yang selama ini telah 
digunakan. Penerapan dari SVLK memberikan dampak terhadap perbaikan tata usaha dan administrasi perindustrian kayu dengan mekanisme yang dapat dilihat oleh semua pihak dan memiliki kredibilitas yang jelas dalam implementasinya. Pemerintah membuat SVLK sebagai upaya untuk merespon pasar yang mulai berorientasi pada kegiatan konsumtif namun tidak lupa akan kelestarian alam.

\section{REFERENSI}

Beck U. 1992. Risk Society: Toward New Modernity. London: Sage Publication.

Bryant LR, dan S Bailey. 2000. Routledge Third World Political Ecology. London (UK) and New York (US): Routledge.

Dauvergne. 2005. Handbook og Global Environmental Politics. USA: Edwar Elgar.

Hawin, M., Irna. Nurhayati, dan Veri. Antoni. 2010. Analisa Hukum Teks Voluntary Partnership Agreement antara Indonesia dan Uni Eropa. Jakarta: Forest Governance and Multistakeholder Foresty Programme.

Heeswijk, I. v., \& Turnhout, E. 2013. The discursive structure of FLEGT (Forest Law Enforcement, Governance and Trade): The negotiation and interpretation of legality in the EU and Indonesia. Forest Policy and Economics.

Hidayat. 2008. Politik Lingkungan: Pengelolaan Hutan Masa Orde Baru dan Reformasi. Jakarta: Yayasan Obor Indonesia.

Komisi Eropa. 2007. Catatan FLEGT Briefing tentang Rencana Aksi Uni Eropa untuk memberikan informasi yang berguna bagi calon FLEGT. Brussel.

Kunkunrat \&, dan Riska Putri Hariyadi. 2017. "Kerja Sama FLEGT-VPA (Forest Law Enforcement Government and Trade-Voluntary Partnership Agreement) Indonesia-Uni Eropa dalam Peningkatan Ekspor Produk Hasil Hutan Indonesia ke Uni Eropa." Jurnal Transborders 1(1).

Lay, Cornelis. 2007. "Nilai Strategis Isu Lingkungan dalam Politik Indonesia." Jurnal IImu Sosial dan Ilmu Politik 11(2): 153-71.

Robbins. 2012. Political Ecology: A Critical Introduction. Oxford: Blackwell Publisher Ltd.

Savirra, Clarissa Diva C. 2014. "Analis Faktor Supply \& Demand Driven Terhadap Insistensi Indonesia Dalam Mewujudkan Perjanjian Kerjasama FLEGT-VPA 2007-2011." Jurnal Analisis Hubungan Internasional 3(3). 